\title{
EFEK PEMBERIAN EKSTRAK AWAR AWAR (Ficus septica) TERHADAP GEJALA KLINIS SCABIES PADA KELINCI
}

(Effect of Awar awar Extract Against Scabies Clinical Sign in Rabbit)

\author{
Susilo, T. ${ }^{1)}$, Kusuma,Y.R. ${ }^{2)}$, Pramu ${ }^{3)}$ \\ 123) Staf Pengajar Sekolah Tinggi Penyuluhan Pertanian Magelang \\ Jl.Magelang-Kopeng Km 7 Purwosari Tegalrejo Magelang Po Boks 15256101 \\ email: pramucinagara@yahoo.com
}

Diterima : 12 Maret 2017 Disetujui : 30 Mei 2017

\begin{abstract}
ABSTRAK
Penanganan penyakit pada kelinci dilakukan dengan memanfaatkan bahan alam yang murah dan aman. Tanaman awar awar (Ficus septica) dimanfaatkan sebagai bahan untuk obat tradisional. Ekstrak dibuat dari daun dan buah awar awar masing masing dipilih lalu dicuci, ditimbang, digerus pada cawan petri, ditambah air, kemudian disaring. Ekstrak kemudian diberikan kepada kelinci dalam kelompok perlakuan.Pemberian perlakuan pada masing-masing kelompok pada hari ke-1 sampai hari ke-3. Kelompok Ed (Ekstrak Daun Awar awar) $3 \mathrm{ml}$ per ekor, Kelompok Eb (Ekstrak Buah Awar awar) $3 \mathrm{ml}$ per ekor, Kelompok K (Kopromec ${ }^{\circledR} 0,01 \mathrm{ml} / \mathrm{kg} \mathrm{BB}$ ), Kontrol Aq (Aduades) $3 \mathrm{ml}$ per ekor. Pengukuran terhadap luka keropeng secara manual (perubahan luas keropeng, kekeringan kulit/ bulu, identifikasi kerokan kulit. Selain progress luka keropeng dilakukan pula pemeriksaan darah rutin.Hasil pengamatan menunjukkan perubahan yakni; berkurangnya ketebalan dan keropeng pada kulit, keringnya luka, dan dimulainya perbaikan jaringan ikat membentuk struktur kulit baru. Analisis statistik menunjukkan perubahan yang nyata pada masing masing kelompok perlakuan sebelum maupun sesudah perlakuan selama limabelas hari $(\mathrm{P}<0,05)$.
\end{abstract}

Kata Kunci : Esktrak awar awar, Scabies, Kelinci

\begin{abstract}
Diseases in rabbits hashandled by utilizing natural materials that are cheap and safety. Awar awar plant (Ficus septica) is used for traditional medicine. The extracts are made from leaves and friuts awar awar each selected and then washed, weighed, crushed on petri dish, add water, and then filtered. Then the extract was given to the rabbits in the treatment group. Treatment for each group on first day tothird day. Ed group (Awar Awar leaf extract) $3 \mathrm{ml}$ per head, Eb Group (Awar Awar friuts extract) $3 \mathrm{ml}$ per head, K Group (Kopromec ${ }^{\circledR} 0.01 \mathrm{ml} / \mathrm{kg} \mathrm{BW}$ ), Aq Control (Aduades) $3 \mathrm{ml}$ per head. Wounds are observed manually (area wound changes, skin wounds dryness, skin scrapings identification) and routine blood test.The result shows that the change are; Decrease thickness and wound on the skin, drying of the wound, and the beginning improvementof connective tissue to a new epithel structure. Statistical analysis showed that significant changes in each treatment group before and after treatment for fifteen days $(P<0.05)$.
\end{abstract}

Keywords :Awar awar Extract, Scabies, Rabbit 


\section{PENDAHULUAN}

Upaya peningkatan kesehatan kelinci ditempuh dengan melaksanakan manajemen pemeliharaan yang baik dan pola agribisnis yang teratur. Di tingkat peternak upaya penanganan penyakit pada kelinci dilakukan dengan memanfaatkan bahan alam yang murah dan aman. Penggunaan bahan alam juga bertujuan untuk menghindari munculnya resistensi obat kimia.

Tanaman awar awar (Ficus septica) telah digunakan untuk pengobatan tradisional sebagai obat luka, bisul, atau penyakit lain yang disebabkan oleh bakteri. Awar awar memiliki kandungan senyawa flavonoid, fenol, kumarin, dan alkaloid (Lansky et al., 2008)

Tujuan Penelitian adalah untuk mengetahui efek pemberian ekstrak daun dan buah awar awar terhadap gejala klinis scabies pada kelinci dan mengetahui kadar zat aktif yang terkandung dalam Ficus septica.

\section{MATERI DAN METODE}

\section{Materi}

36 ekor kelinci dewasa didapat dari pasar tradisional di sekitar Kabupaten Magelang dibagi menjadi 4 kelompok; Kelompok Ed (Ekstrak Daun Awar awar), Kelompok Eb (Ekstrak Buah Awar awar), Kelompok K (Kopromec ${ }^{\circledR}$ oral), Kontrol Aq (Aduades). Kelinci diseragamkan berdasarkan berat badan, umur, jenis kelamin, dan bangsa. Kelinci yang dipilih memiliki gejala klinis scabies seragam yang ditandai dengan terdapatnya luka/ keropeng seluas 1-3 cm di telinga atau kaki. Peneguhan diagnosa scabies dilakukan dengan pemeriksaan mikroskopis keberadaan ektoparasit (Psoroptes $s p$,
Chorioptes sp, atau Sarcoptes scabiei)

pada sampel kerokan kulit.

\section{Metode}

Penelitian dirancang dengan menggunakan rancangan acak kelompok.Kelinci dipelihara pada kandang batre yang terpisah dengan perlakukan pemeliharaan yang sama. Semua kelinci diambil darahnya pada hari ke-1 dan hari ke-15 untuk dilakukan pemeriksaan darah. Pemberian perlakuan pada masing-masing kelompok pada hari ke-1 sampai hari ke-3. Kelompok Ed (Ekstrak Daun Awar awar) 3 $\mathrm{ml}$ per ekor, Kelompok Eb (Ekstrak Buah Awar awar) $3 \mathrm{ml}$ per ekor, Kelompok $\mathrm{K}$ (Kopromec $^{\circledR}$ 0,01 ml/kg BB), Kontrol Aq (Aduades) $3 \mathrm{ml}$ per ekor. Pengukuran terhadap luka keropeng secara manual (perubahan luas keropeng, kekeringan kulit/ bulu, identifikasi kerokan kulit. Selain progress luka keropeng dilakukan pula pemeriksaan darah rutin.

Daun dan buah awar awar masing masing dipilih lalu dicuci bersih dengan air mengalir, ditimbang masing masing 50 gram, digerus pada cawan petri, ditambah air $30 \mathrm{cc}$, disaring menggunakan kertas saring daun dan buah Awar awar masing masing diambil $3 \mathrm{cc}$ menggunakan pipet ukur untuk diberikan kepada kelinci dalam kelompok perlakuan.

Data yang dicatat adalah gambaran luka kulit, perubahan gejala klinis, dan gambaran sel darah. Data yang diperoleh dilakukan analisis secara diskriptif dan statistika. Analisis statistika digunakan untuk membandingkan gambaran sel darah dan gejala klinis kulit sebelum maupun sesudah perlakuan. 


\section{HASIL DAN PEMBAHASAN}

Daun mempunyai kandungan fenol sebanyak 0,623\% lebih tinggi dari pada buah dan akar. Kadar flavonoid dan alkaloid bagian daun lebih tinggi dari pada bagian akar maupun buah. Fenol merupakan salah satu senyawa yang dalam industri digunakan untuk membunuh jenisserangga. Fenol umumnya juga digunakan sebagai zat antiseptik. Selain kemampuan Ficus septica sebagai anti radang, antiseptik, anti bakteri, dan anti jamur telah banyak diteliti, komponen alkaloid, flavonoid, dan fenol pada Ficus septicamampu mengurangi gejala klinis scabies.

Efek fenol adalah racun bagi tungau scabies. Peran bakteriostatik berasal dari senyawa formaldehida dan fenol bekerja sinergis mencegah dan mengontrol mikrobia hal ini membuat infeksi sekunder yang menyertai scabies juga bisa hilang (Pszczola, 1995).

Tabel 1. Senyawa Kimia Pada Daun, Akar dan Buah Awar Awar

\begin{tabular}{|l|r|r|r|}
\hline \multicolumn{1}{|c|}{ Kadar } & Fenol \% & Flavonoid \% & Alkaloid \% \\
\hline Buah & 0,093 & 0,028 & 0,023 \\
\hline Akar & 0,219 & 0,054 & 0,033 \\
\hline Daun & 0,623 & 0,082 & 0,042 \\
\hline
\end{tabular}

Penelitian telah banyak dilakukan untuk mengetahui aktifitas flavonoid, fenol, dan alkaloid pada berbagai tanaman. Flavonoid merupakan senyawa pereduksi yang mampu menghambat reaksi oksidasi. Mekanisme kerja flavonoid berfungsi sebagai antibakteri dengan cara membentuk senyawa kompleks terhadap protein extraseluler yang mengganggu keutuhan membran sel bakteri. Mekanisme kerjanya dengan cara mendenaturasi protein sel bakteri dan merusak membran sel tanpa dapat diperbaiki lagi.Senyawa alkaloid memiliki mekanisme penghambatan dengan cara mengganggu komponen penyusun peptidoglikan pada sel bakteri, sehingga lapisan dinding sel tidak terbentuk secara utuh dan menyebabkan kematian sel tersebut (Juliantina et al., 2008).

Pengamatan pada kelinci selama 15 hari menunjukkan perubahan yakni; berkurangnya ketebalan dan keropeng pada kulit, keringnya luka, dan dimulainya perbaikan jaringan ikat membentuk struktur kulit baru. Tabel 2 menunjukkan hasil perubahan luka keropeng pada telinga di hari pertama dan hari ke-15. Parameter pengukuran perubahan meliputi perubahan luas luka, perubahan tingkat kekeringan dan ketebalan keropeng. Analisis statistik menunjukkan perubahan yang nyata pada masing masing kelompok perlakuan sebelum maupun sesudah perlakuan selama limabelas hari $(\mathrm{P}<0,05)$. 
Tabel 2. Luka Keropeng pada Telinga di Hari Pertama (H1) dan Hari ke-15 (H15).

\begin{tabular}{c|c|c|c|c|}
\hline Luka/ keropeng/ basah $\left(\mathrm{mm}^{2}\right)$ & $\mathrm{K}$ & $\mathrm{Ed}$ & $\mathrm{Eb}$ & $\mathrm{Ko}$ \\
\hline H1 & $21,00 \pm 2,60$ & $20,22 \pm 1,82$ & $20,28 \pm 2,83$ & $18,00 \pm 2,64$ \\
\hline H15 & $21 \pm 2,40$ & $10,22 \pm 0,96$ & $9,94 \pm 1,77$ & $7,56 \pm 3,07$ \\
\hline
\end{tabular}

Keterangan: Kelompok Ed (Ekstrak Daun Awar awar), Kelompok Eb (Ekstrak Buah Awar awar), Kelompok KO (Kopromec® oral), Kontrol (Aduades).

Penelitian juga dilakukan untuk analisis hematologi yang diperolehdari mengamati gambaran hematologi kelinci. darah kelinci baik kontrol maupun Parameter hematologi yang digunakan yaitu perlakuan ditampilkan pada Tabel 3 dan jumlah eritrosit dan jumlah leukosit. Hasil Tabel 4.

Tabel 3. Jumlah Sel Darah Merah di Hari Pertama (H1) dan Hari ke-15(H15)

\begin{tabular}{|c|c|c|c|c|}
\hline Eritrosit $\left(\mathrm{JUTA} / \mathrm{mm}^{3}\right)$ & $\mathrm{K}$ & $\mathrm{Ed}$ & $\mathrm{Eb}$ & Ko \\
\hline H1 & $5,32 \pm 0,185$ & $5,81 \pm 0,679$ & $5,38 \pm 0,215$ & $5,21 \pm 0,106$ \\
\hline H15 & $5,37 \pm 0,244$ & $5,86 \pm 0,627$ & $5,63 \pm 0,467$ & $5,69 \pm 0,565$ \\
\hline
\end{tabular}

Keterangan: Kelompok Ed (Ekstrak Daun Awar awar), Kelompok Eb (Ekstrak Buah Awar awar), Kelompok KO (Kopromec® oral), Kontrol (Aduades).

Hasil analisis dengan parameter tidak nyata $(\mathrm{P}>0,05)$. Perlakuan pemberian jumlah eritrosit menunjukkan rerata 5,32- obat kelompok Ed, Eb, dan Ko tidak $5,37 \mathrm{juta} / \mathrm{mm}^{3}$ pada kelinci kontrol.Rerata berpengaruh pada jumlah eritrosit selama jumlah eritrosit menunjukkan antara kelinci perlakuan.

kontrol dengan kelinci perlakuanberbeda

Tabel 4. Rerata Jumlah Sel Darah Putih di Hari Pertama (H1) dan Hari ke-15 (H15).

\begin{tabular}{|c|c|c|c|c|}
\hline Leukosit $\left(\mathrm{ribu} / \mathrm{mm}^{3}\right)$ & $\mathrm{K}$ & $\mathrm{Ed}$ & $\mathrm{Eb}$ & Ko \\
\cline { 2 - 5 } $\mathrm{H} 1$ & $4,63 \pm 0,852$ & $4,78 \pm 0,963$ & $5,67 \pm 1,037$ & $6,22 \pm 0,914$ \\
\hline $\mathrm{H} 15$ & $5,41 \pm 0,896$ & $4,33 \pm 0,852$ & $5,17 \pm 1,037$ & $5,33 \pm 1,148$ \\
\hline
\end{tabular}

Keterangan: Kelompok Ed (Ekstrak Daun Awar awar), Kelompok Eb (Ekstrak Buah Awar awar), Kelompok KO (Kopromec ${ }^{\circledR}$ oral), Kontrol (Aduades).

Jumlah total leukosit di dalam leukosit menurun seiring dengan proses sirkulasi darah di awal percobaan adalah kesembuhan yang ditandai dengan merupakan respon tubuh dalam berkurangnya ketebalan dan keropeng kulit, menghadapi infeksi ektoparasit. Penurunan luka menjadi kering, dan dimulainya rerata jumlah leukosit pada kelompok perbaikan jaringan ikat membentuk struktur perlakuan sejalan dengan waktu proses kulit baru. Selama perlakuan jumlah penyembuhan luka selama 15 hari. leukosit masih dalam kisaran normal. Penurunan rerata jumlah leukosit tidak Jumlah sel darah putih kelinci 3,0-12,5 x tampak secara nyata $(\mathrm{P}>0,05)$ pada masing- $10^{3} / \mathrm{mm}^{3}$ (Malole dan Utami, 1989).

masing kelompok perlakuan sebelum maupun sesudah pengobatan. Jumlah

Saat terjadi infeksi parasit eosinofil diproduksi dalam jumlah tinggi dan 
dimigrasikan menuju sel sasaran dengan bantuan mediator eosinophil chemotacticfactor of anaphilaxis (ECF-A) (Kresno, 2001).Eosinofil bertindak sebagai selfagosit terhadap komponen asing yang telah bereaksi dengan antibodi. Peningkatan jumlah eosinofil (eosinofilia) ini merupakan gejala klinis infeksi parasit dan reaksi alergi pada tubuh kelinci(Martini et al., 1992).

Levine (1994) menjelaskan bahwa pengobatan menggunakan obat alami lebih murah dan praktis. Jika pengobatan scabies ini menggunakan bahan kimia tentunya akan diperlukan biaya yang harga lebih dari itu. Sehingga bahan alami lebih ekonomis untuk dikembangkan. Selain itu menjaga kebersihan sangat penting untuk menjaga terjadinya infestasi parasit dan reinfeksinya.

\section{KESIMPULAN DAN SARAN}

\section{Kesimpulan}

Ekstrak daun dan buah dari Awar awar (Ficus septica) mampu mengurangi gejala klinis scabiespada kelinci. Gambaran gejala klinis berdasarkan pada berkurangnya;luas luka, kekeringan luka dan ketebalan keropeng. Komponen alkaloid, flavonoid, dan fenol pada Ficus septica mampu mengurangiinfeksi sekunder yang menyertai gejala scabies.

\section{Saran}

Pencegahan dan pengendalian penyakit kudis perlu diperhatikan pemanfaatan bahan alam yang murah dan aman serta menghindari munculnya resistensi obat.

\section{DAFTAR PUSTAKA}

Juliantina, F., D.A. Citra, B. Nirwani. 2008. Manfaat Sirih Merah (Pipercrocatum) Sebagai Agen Anti
Bakterial Terhadap Bakteri Gram Positif dan Gram Negatif. UII. Yogyakarta http://journal.uii.ac.id

Kresno SB. 2001. Imunologi : Diagnosis dan Prosedur Laboratorium edisi ke4. Jakarta : Balai Penerbit FKUI

Lansky, E. P., Paavilainen, H. M., Pawlus, A. D., and Newman, R. A., 2008, Ficus spp. (fig): Ethnobotany and potential as anticancer and antiinflammatory agents, Journal of Ethnopharmacology, 119 : 195-213.

Levine, N.D. 1994. Buku Pelajaran Parasitologi Veteriner (terjemahan). Gajah Mada University Press, Yogyakarta. hlm. 325 - 327

Malole MBM dan Utami S. 1989. Penggunaan Hewan Percobaan di Laboratorium. Departemen Pendidikan dan Kebudayaan. Direktorat Jendral Pendidikan Tinggi. Pusat Antar Universitas Bioteknologi. Bogor : Institut Pertanian Bogor.

Martini F, Obar WC, Garrison CW dan Wekh K. 1992. Fundamental of Anatomy and Physiologi, 2nd ed. New Jersey : A Simon and Schucter Company. Englewood Cliffs.

Pszczola, D.E. 1995. Tour Highlight Production and Uses of Smoke Based Flavors. Food Tech. 49(1): 70 -74 . 